\title{
Development and Optimisation of Drying Parameters for Low-Cost Hybrid Solar Dryer Using Response Surface Method
}

\author{
Adeodu 0. Adefemi, Daniyan A. Ilesanmi \\ Department of Mechanical and Mechatronics Engineering, Afe Babalola University, Ado-Ekiti, Nigeria \\ Email: aadeodu@asme.org, afolabiilesanmi@yahoo.com
}

How to cite this paper: Adefemi, A.O. and Ilesanmi, D.A. (2018) Development and Optimisation of Drying Parameters for Low-Cost Hybrid Solar Dryer Using Response Surface Method. Journal of Sustainable Bioenergy Systems, 8, 23-35.

https://doi.org/10.4236/jsbs.2018.82002

Received: November 15, 2017

Accepted: June 15, 2018

Published: June 19, 2018

Copyright (c) 2018 by authors and Scientific Research Publishing Inc. This work is licensed under the Creative Commons Attribution International License (CC BY 4.0).

http://creativecommons.org/licenses/by/4.0/

\begin{abstract}
After harvest and storage problems are major dilemma, which requires to be looked into carefully in developing nation like Nigeria. This paper presents a development of low-cost hybrid solar dryer for food preservation with the objective of setting optimum drying parameters for the preservation of cassava and tomato products. The work was carried out by designing, constructing and finally evaluating the hybrid dryer for effective performance. The optimization of the drying parameters was done using composite technique (Response surface method). The assessment of the dryer shows that $150 \mathrm{Kg}$ cassava mesh and 5000 grams of tomato with $35 \%$ and $94 \%$ moisture content, respectively were dried to $100 \mathrm{Kg}$ and $334 \mathrm{~g}$ with $10 \%$ moisture level for 4 hours and 11 hours respectively, for cassava and tomato. The optimization result shows that the dryer will perform optimally with drying temperature of $62^{\circ} \mathrm{C}$ and $48^{\circ} \mathrm{C}$ for cassava and tomato respectively with $24 \%$ and $91 \%$ moisture uptake. Therefore, sustainable techniques for preservation of food are essentially required. Hybrid solar dryer is an alternative to consider in the situation.
\end{abstract}

\section{Keywords}

Drying Parameters, Hybrid Solar Drying, Post-Harvesting, Raised Platform, Sustainability

\section{Introduction}

Drying process is one of the ubiquitous forms of conservation of food items that prolongs the food item's shelf life. This type of operation is described as concurrent energy and mass transfer where water content is withdrawn from food material via superheated air [1]. A solar heating device is harnessed to boost the 
thermal energy stored in the dryer in the day time, or draw excess heat from the dryer to the heat storage area [2]. In less developed nations, the conventional type of drying is by open air, which usually increases the rate of food contamination and nutritional deterioration [2]. As a result of recent tides toward exorbitant cost implication of fossil fuels and skepticism toward oncoming cost, availability and sustainability, utilization of solar energy in food conservation has presumably increased, thus becomes highly profitably realistic in the future.

Solar dryers have merits over the conventional sun drying if correctly designed [2]. Quick drying rate has been provided by heating the air above ambient temperature, thereby allowing the air to move faster through the dryer. As good as the use of dryer in combating the risk of food spoilage and improving nutritional quality, caution must be taken when drying some vegetables in that spontaneous drying will lead to mass destruction of the product.

Several works were conducted on solar dryer to test the energy efficiency and cost effectiveness using different kinds of foods and vegetables. According to Sharma [3] drying of tomatoes and mushrooms can be cost and energy effectual with solar dying. According to Karathanos and Belessiot [4], solar drying experiments were flourishingly implemented with currants, plums and apricots fruits. Also, Bala et al. [5], a tunnel dryer covered with a flat plate solar collector was utilized in the drying of slices of pineapple. A direct kind of congenital convective solar dryer was examined with fruits making interactions between drying kinetics and heat balance (Gbaha et al. [6]. Thepent [7] tried out a combined solar tunnel dryer with biogas for perpetual uninterrupted drying of banana and mango. The dryer worked under solar radiation during the day and make use of the biogas as an auxiliary heat source, operating simultaneously both day time and night time. Desiccants are a chemicals related adsorbent, which sponges moisture that comes with physical and chemical changes [8]. Majority of absorbents are mostly liquids and solids. Silica gel has strong affinity moisture and releases it at a higher temperature. A fixed desiccant bed was used in a solar dryer during day and extended the drying process through nighttime [9]. Riyad and Jacques [10] adopted a fixed silica gel bed integrated to an apricot solar dryer to shortening the drying cycle from 55 to 44 hours. Gurtas and Evranuz [11] utilized low temperature up to $40^{\circ} \mathrm{C}$ silica gel for drying mushrooms lowering the Maillard browning reaction rate.

This paper is aimed at developing a low-cost sustainable hybrid solar dryer for vegetables and tubers (tomatoes and cassava) with the objectives of examine the energy efficiency of the dryer in term of drying time of the products and the optimisation of the drying parameters for the dryer.

\section{Materials and Methods}

\section{Study Site}

Ogun is a state in south western part of Nigeria created in 1976. It borders

Lagos state in south, Oyo and Osun states to the north, Ondo to the east and 
Republic of Benin to the west. It is located on the map with coordinates $7^{\circ} \mathrm{N}, 3^{\circ}$ 35 "E with a total population of 3,751,140 (2006b Census). It has land mass of $16,980.55 \mathrm{~km}^{2}$ and total GDP/Capital of \$2740 [12].

A sustainable drying system remains a captious factor for the design and construction of food preservation systems in Nigeria, particularly in the rustic communities. As part of the alms toward ameliorating drying technology in $\mathrm{Ni}$ geria, development of a hybrid solar drying system was initiated. The dryer was installed at Olokola Farm in Obafemi-Owode Local Government of Ogun-State, Nigeria purposely for drying of mash cassava tubers for conversion to other products like Laafun or Starch and also other perishable edibles.

\subsection{Design Description}

The design integrates solar and indirect heating drying apartment. The roof of the constructed drying facility was covered with white thermo plastics and the inside bears trays on an elevated platforms. The dryer utilizes solar energy amid daytime while heat is provided via the apartment in the evening to further drying, if necessary. The heating apartment was constructed with hollow drum fitted from outside. The maximum drying temperature reached was $65^{\circ} \mathrm{C}$ with a drying mass rate of $100-160 \mathrm{~kg}$ wet mash/day and an average final moisture content of $10 \%$. The processors now have advantage of working their products any time with little or no reliance on the use of wood.

\subsection{Design Consideration}

\section{Design of the Dryer}

The system comprises of four parts, the drying apartment constructed with brickwork scaling $6.8 \mathrm{~m}$ in length and width respectively, with four sides without window. The openings with net provide vents (lower and upper) for moisture escape and permits natural air flow in the system. The polycarbonate material serves dual purposes as roof and solar radiator. Two aluminium drums inserted to the back wall and projected into the drying apartment provide means of radiating heat into the apartment. There are two alternatives to consider in placing the products; a rack system or an elevated metal stand. The elevated stand type was chosen due to easy adaptability of the design whereby the surface for drying was designed with stainless steel and angle iron as stands. The surface for drying is twice it degree as energy receptor when the surface is illuminated. Heat is reserved and alienated unto the product to be dried by spreading thinly on it.

\section{Design of the Drying Apartment}

The major design considerations of the drying apartment are listed as follow:

[13]. Figure 1 shows the design of the drying chamber.

1) Size in mass of product to be dried per batch or day and capacity of the drying cabinet to contain the material.

2) Cubage of the dryer ( $\mathrm{kg} / \mathrm{batch}$ ).

3) Method of loading and removing the product. 


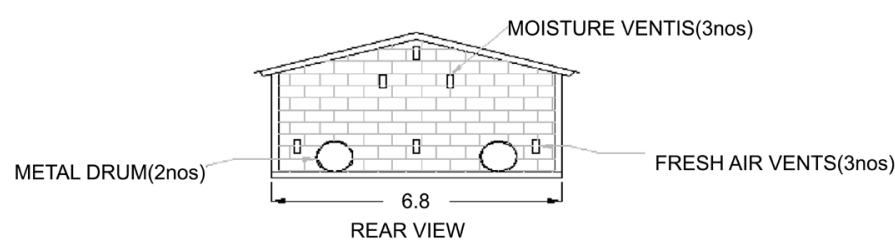

TRANSPARENT ROOFING SHEET
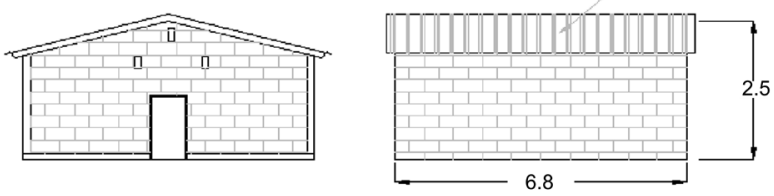

FRONT VIEW SIDE VIEW

DIMENSIONS IN METRES

Figure 1. Design of the Drying Chamber. Source: [2].

4) Materials for dryer and tray fabrication.

5) Modality of channeling hot air through the product to be dried.

6) Potent dissemination of hot air through the dryer.

7) Openings as a means of escape of the warm moist air from the drying apartment.

\subsection{Thermodynamics of Drying within Chamber}

The mass of hot air that is necessary to dry specific mass of the product is determined as follows:

\section{Energy Balance Equation}

The energy balance equation expresses the concept as follows:

The energy accessible from the air via the product in the dryer must be the same as energy required to vapourise the moisture content. The withdrawal of moisture from a surface via vapourization demands a measurable heat equitable to the latent heat of vapourization of water plus an amount of air flow over the surface of the product to push away the water vapour released. Therefore, the expectation in solar dryer is to achieve optimum temperature $T_{f}$ and air flow $m_{a}$ to drive away certain amount of water, $m_{w}$ Therefore, it is calculated thus:

$$
m_{w} L=\left(T_{F}-T\right)_{i} m_{a} C_{p}
$$

where $m_{w}$ is the mass of water vapourized, $\mathrm{L}$ is the latent heat of vapourization, ma is the mass of air disseminated, $C_{p}$ is the specific heat capacity of dry air and $T_{f} T_{i}$ are the final and initial temperatures respectively.

Consequently, the volume of air can be determined using gas laws:

$$
\frac{V_{a i r}}{m_{v}}=\left(\frac{m_{a}}{m_{v}}\right)\left(\frac{R T}{P}\right)
$$

$$
\text { Therefore, } V_{\text {air }}=\frac{m_{a} R T}{P}
$$

where $m_{w}$ the quantity of water vapourised can be evaluate from moisture ratio scale, or using energy balance equation. Due to the fact that vapour pressure of 
bound water in hygroscopic material is less than saturation, the impact of bound water is also to be taken into consideration. Also, the value of the vapour pressure must be relatively higher than the latent heat value selected. The expressions are useful in evaluating different parameters as mentioned. For this purpose, these were used in evaluating the mass of air needed for drying tomatoes and mashed cassava tuber products [14].

Table 1 shows the moisture contents and permissible temperature for different products.

\subsection{Performance Evaluation of the Hybrid Dryer}

The following criteria were taken to consideration in the evaluation of the dryer:

1) Direct technique of trapping solar energy

2) Drying temperature in the range of $50^{\circ} \mathrm{C}-70^{\circ} \mathrm{C}$

3) Discretional method of heating

4) Direction of air flow.

An unload examination of the heat gradient of the developmental dryer was carried out on the $15^{\text {th }}$ of January 2016 with temperature condition, warmest $\left(32.2^{\circ} \mathrm{C}\right)$, coldest $\left(22.4^{\circ} \mathrm{C}\right)$ and precipitation $(1 \mathrm{~mm})$ The temperature was clocked at the space of 20 minutes interval by means of Hobo data clocking device which was set on the stainless steel drying surface. A maximum temperature of $65^{\circ} \mathrm{C}$ was achieved, which was within the limit of design consideration temperature acceptable for drying cassava and some other edible products.

$5000 \mathrm{~g}$ of fresh tomatoes and $150 \mathrm{~kg}$ of pulverized cassava mash with a moisture content of about $94 \%$ wet basis and $35 \%$ wet basis respectively were packed

Table 1. Summary of moisture contents with permissible drying temperature for different products.

\begin{tabular}{cccc}
\hline \multirow{2}{*}{ Products } & & & Permissible Drying \\
\cline { 2 - 3 } Maize & Initial Moisture (\%) & Final Moisture $(\%)$ & Temperature $\left({ }^{\circ} \mathrm{C}\right)$ \\
Carrots & 75 & 15 & 60 \\
Wheat & 20 & 5 & 75 \\
Onions & 80 & 16 & 50 \\
Potato & 75 & 4 & 55 \\
Fish & 75 & 13 & 75 \\
Banana & 80 & 15 & 50 \\
Coffee & 50 & 15 & 70 \\
Cotton & 50 & 11 & 75 \\
Ground nut & 40 & 7 & 75 \\
Leather & 50 & 9 & 30 \\
Fabrics & 50 & 18 & 35 \\
\hline
\end{tabular}

Source: [15]. 
into the dryer at 8:05 $\mathrm{AM}$ and 12.05 PM respectively, to achieve a targeted $10 \%$ moisture content simultaneously (minimum permissible moisture content). The moisture content of the products was measured with a moisture meter at space of time of twenty minutes. The energy utilized for the dryer was gotten from the solar rays and addition heat from the drying chamber. $100 \mathrm{~kg}$ dry weight of cassava was weighed after drying time of 4 hours, while $334 \mathrm{~g}$ dry weight of tomatoes was weighed after drying time of 11 hours at the targeted moisture content of $10 \%$ for both products. Figure 2 and Figure 3 show the physical structure of the drying chamber and the progress of drying process of the products respectively.

The optimisation of the drying process was done using response surface methodology.

\section{Results and Discussion of Results}

Table 2 and Table 3 show the results of the drying process of cassava and tomatoes.

Figure 4(a) and Figure 5(a) show the drying profiles for cassava and tomato products. These were responses of the products to drying temperature of the

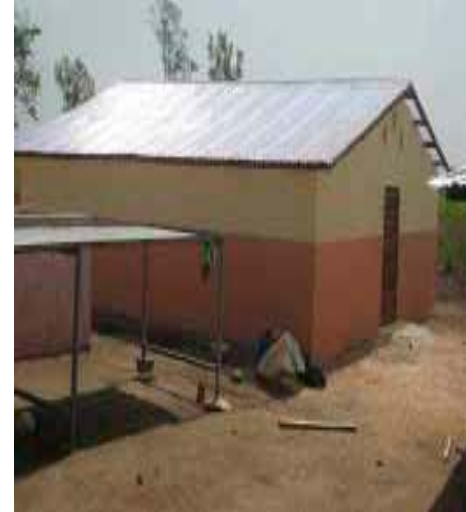

(a)

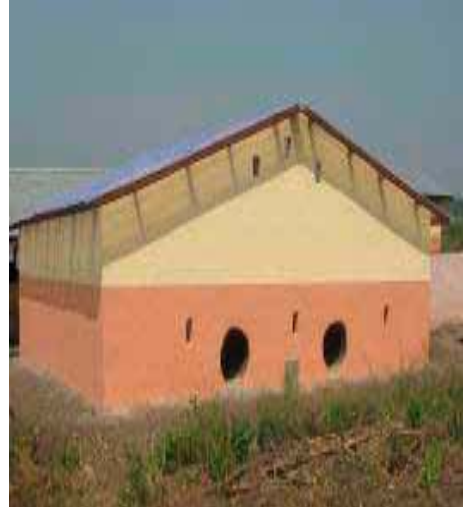

(b)

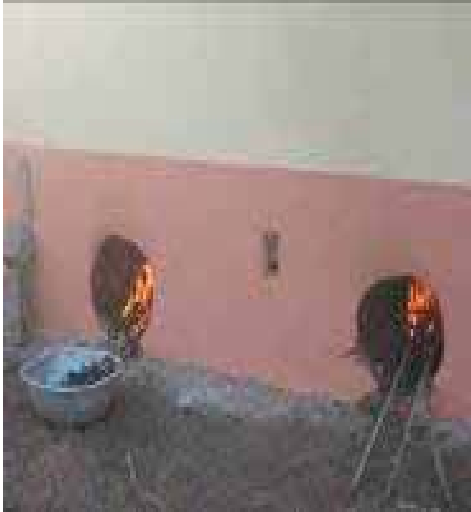

(c)

Figure 2. (a) Drying House; (b) Plastic Roof; (c) Heating Chamber.

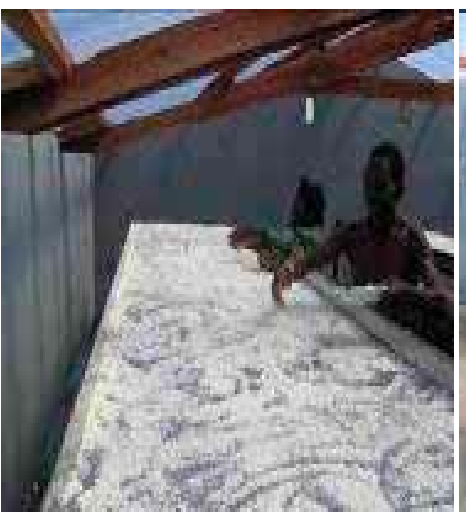

(a)

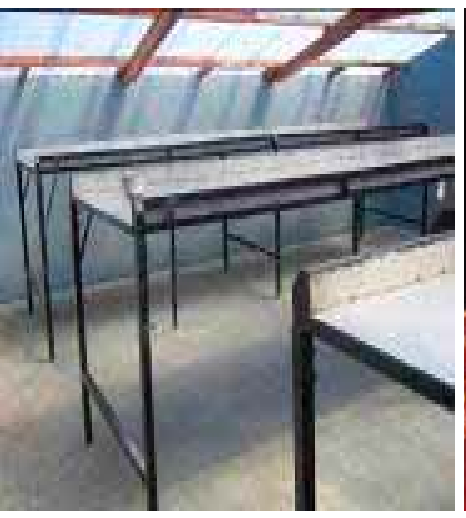

(b)

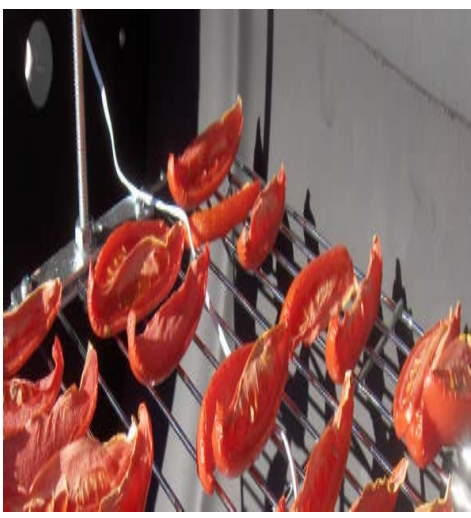

(c)

Figure 3. (a) Drying testing; (b) Cassava Drying in Progress; (c) Tomato Drying in Progress. 
Table 2. Summary of drying process of cassava products.

\begin{tabular}{ccccccc}
\hline $\begin{array}{c}\text { Drying } \\
\text { Temp }\left({ }^{\circ} \mathrm{C}\right)\end{array}$ & $\begin{array}{c}\text { Drying } \\
\text { Time }(\mathrm{Min})\end{array}$ & $\begin{array}{c}\text { Mass on Wb } \\
(\mathrm{Kg})\end{array}$ & $\begin{array}{c}\text { mass on Db } \\
(\mathrm{Kg})\end{array}$ & $\begin{array}{c}\text { mass of } \\
\mathrm{H}_{2} \mathrm{O}\end{array}$ & $\begin{array}{c}\text { \% moisture } \\
\text { retained }\end{array}$ & $\begin{array}{c}\text { \% moisture } \\
\text { uptake }\end{array}$ \\
\hline 60 & $12: 05$ & 150.00 & 97.00 & 52.50 & 35.00 & 0.00 \\
62 & $12: 25$ & 146.50 & 97.00 & 49.10 & 32.70 & 2.30 \\
62 & $12: 45$ & 142.00 & 97.00 & 44.50 & 30.40 & 2.30 \\
65 & $13: 05$ & 136.40 & 97.00 & 38.90 & 27.40 & 3.00 \\
65 & $13: 25$ & 130.70 & 97.00 & 33.28 & 24.40 & 3.00 \\
65 & $13: 45$ & 124.80 & 97.00 & 27.59 & 21.10 & 3.30 \\
65 & $14: 05$ & 119.96 & 97.00 & 22.58 & 18.10 & 3.00 \\
63 & $14: 25$ & 115.50 & 97.00 & 18.00 & 15.10 & 3.00 \\
64 & $14: 45$ & 112.60 & 97.00 & 15.00 & 12.60 & 2.50 \\
64 & $15: 05$ & 109.80 & 97.00 & 12.40 & 11.10 & 1.50 \\
63 & $15: 25$ & 109.00 & 97.00 & 12.10 & 10.60 & 0.50 \\
64 & $15: 45$ & 107.00 & 97.00 & 10.90 & 10.20 & 0.40 \\
60 & $16: 05$ & 100.00 & 97.00 & 3.00 & 10.00 & 0.20 \\
\hline
\end{tabular}

Table 3. Summary of drying process of tomato products.

\begin{tabular}{|c|c|c|c|c|c|c|}
\hline $\begin{array}{c}\text { Drying } \\
\text { Temp }\left({ }^{\circ} \mathrm{C}\right)\end{array}$ & $\begin{array}{l}\text { Drying Time } \\
\quad \text { (Min) }\end{array}$ & $\begin{array}{l}\text { Mass on } \\
\mathrm{Wb}(\mathrm{g})\end{array}$ & $\begin{array}{l}\text { Mass on } \\
\mathrm{Db}(\mathrm{g})\end{array}$ & $\begin{array}{c}\text { Mass of } \\
\mathrm{H}_{2} \mathrm{O}\end{array}$ & $\begin{array}{l}\text { \%moisture } \\
\text { retained }\end{array}$ & $\begin{array}{c}\text { \%moisture } \\
\text { uptake }\end{array}$ \\
\hline 31 & 08:05 & 5000.00 & 300.00 & 4700.00 & 94.00 & 0.00 \\
\hline 31 & 08:25 & 4940.00 & 300.00 & 4640.00 & 92.80 & 1.20 \\
\hline 33 & 08:45 & 4825.04 & 300.00 & 4525.00 & 91.60 & 1.20 \\
\hline 34 & 09:05 & 4642.54 & 300.00 & 4342.54 & 90.10 & 1.50 \\
\hline 36 & 09:25 & 4399.36 & 300.00 & 4099.36 & 88.30 & 1.80 \\
\hline 36 & 09:45 & 4105.44 & 300.00 & 3805.45 & 86.50 & 1.80 \\
\hline 40 & 10:05 & 3752.68 & 300.00 & 3452.68 & 84.10 & 2.40 \\
\hline 42 & $10: 25$ & 3365.94 & 300.00 & 3065.94 & 81.70 & 2.40 \\
\hline 43 & 10:45 & 2969.19 & 300.00 & 2669.19 & 79.30 & 2.40 \\
\hline 48 & 11:05 & 2565.49 & 300.00 & 2265.49 & 76.30 & 3.00 \\
\hline 52 & $11: 25$ & 2167.67 & 300.00 & 1867.68 & 72.80 & 3.50 \\
\hline 55 & 11:45 & 1826.05 & 300.00 & 1526.04 & 70.40 & 2.40 \\
\hline 60 & $12: 05$ & 1534.41 & 300.00 & 1234.41 & 67.60 & 2.80 \\
\hline 62 & $12: 25$ & 1294.30 & 300.00 & 994.30 & 64.80 & 2.80 \\
\hline 62 & $12: 45$ & 1102.46 & 300.00 & 802.47 & 62.00 & 2.80 \\
\hline 65 & 13:05 & 942.73 & 300.00 & 642.73 & 58.30 & 3.70 \\
\hline 65 & $13: 25$ & 814.73 & 300.00 & 514.73 & 54.60 & 3.70 \\
\hline 65 & $13: 45$ & 714.70 & 300.00 & 414.70 & 50.90 & 3.70 \\
\hline 65 & 14:05 & 637.91 & 300.00 & 337.34 & 47.20 & 3.70 \\
\hline 63 & $14: 25$ & 583.68 & 300.00 & 283.23 & 44.40 & 2.80 \\
\hline 64 & $14: 45$ & 542.81 & 300.00 & 242.81 & 41.60 & 2.80 \\
\hline 64 & $15: 05$ & 511.15 & 300.00 & 211.15 & 38.90 & 2.70 \\
\hline
\end{tabular}




\section{Continued}

\begin{tabular}{lllllll}
\hline 63 & $15: 25$ & 486.06 & 300.00 & 186.06 & 36.40 & 2.50 \\
64 & $15: 45$ & 464.77 & 300.00 & 164.77 & 33.90 & 2.50 \\
60 & $16: 05$ & 446.40 & 300.00 & 146.40 & 31.50 & 2.40 \\
58 & $16: 25$ & 429.95 & 300.00 & 129.90 & 29.10 & 2.40 \\
55 & $16: 45$ & 415.22 & 300.00 & 115.23 & 26.80 & 2.30 \\
42 & $17: 05$ & 401.73 & 300.00 & 101.73 & 24.50 & 2.30 \\
42 & $17: 25$ & 389.18 & 300.00 & 89.18 & 22.20 & 2.30 \\
40 & $17: 45$ & 378.62 & 300.00 & 78.62 & 20.20 & 2.00 \\
33 & $18: 05$ & 369.67 & 300.00 & 69.67 & 18.40 & 1.80 \\
33 & $18: 25$ & 361.36 & 300.00 & 61.36 & 16.60 & 1.80 \\
34 & $18: 45$ & 353.84 & 300.00 & 53.84 & 14.90 & 1.70 \\
34 & $19: 05$ & 346.71 & 300.00 & 46.71 & 13.20 & 1.70 \\
34 & $19: 25$ & 339.87 & 300.00 & 39.87 & 11.50 & 1.70 \\
34 & $19: 45$ & 333.99 & 300.00 & 33.99 & 10.00 & 1.50
\end{tabular}

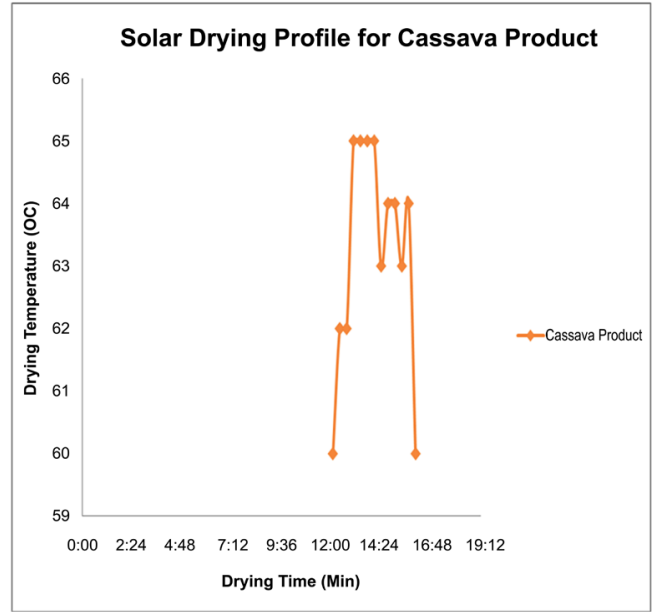

(a)

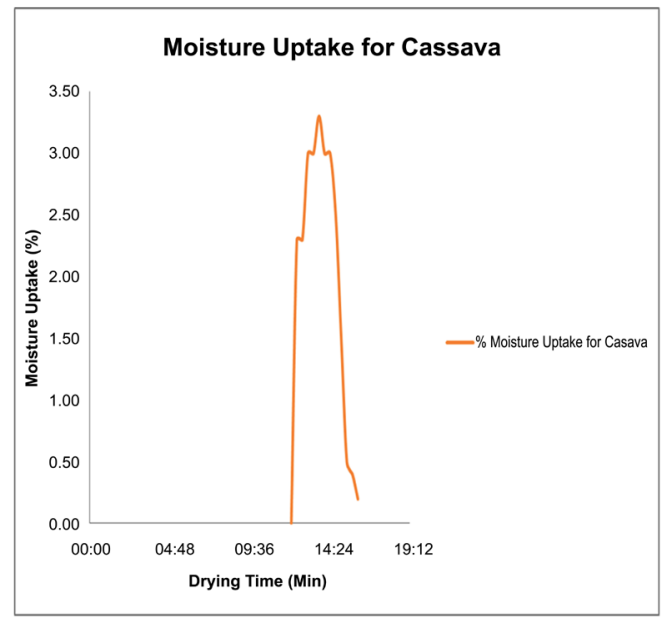

(b)

Figure 4. (a) Drying profile for cassava product; (b) Moisture uptake profile for cassava product.

dryer per time. In Figure 4, the drying of cassava started at 12:05 pm in the mid-day at the drying temperature of $60^{\circ} \mathrm{C}$. Between the periods of 12:05 - 1:05 $\mathrm{pm}$, the drying temperature steadily increases to $65^{\circ} \mathrm{C}$. The temperature was very high at this period as a result of combination of heat from the drying chamber and solar energy. A steady drying temperature was observed at $65^{\circ} \mathrm{C}$ for about an hour during the course of the drying process. The temperature flunctuately dropped between $64^{\circ} \mathrm{C}$ and $63^{\circ} \mathrm{C}$ at $2: 25$ to $3: 45 \mathrm{pm}$, which finally dropped to $60^{\circ} \mathrm{C}$ at 4:05 pm. The flunctuating drop in the drying temperature was due to drop in solar energy (weather condition).

In Figure 6, the drying process for tomato commenced at 8:05 am with drying temperature of $31^{\circ} \mathrm{C}$. The drying temperature was very low at this period due to only heat from the drying chamber was available for the drying process. A steady 


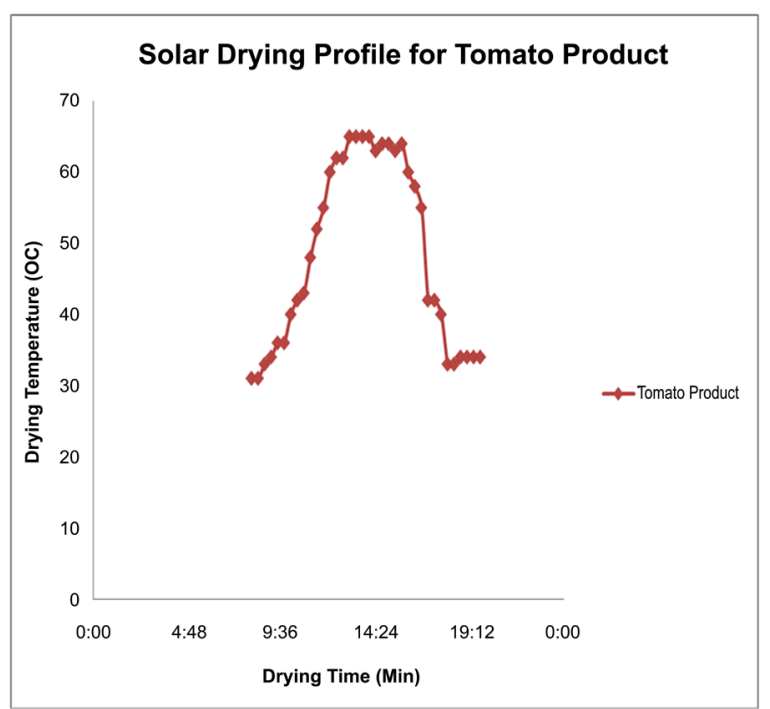

(a)

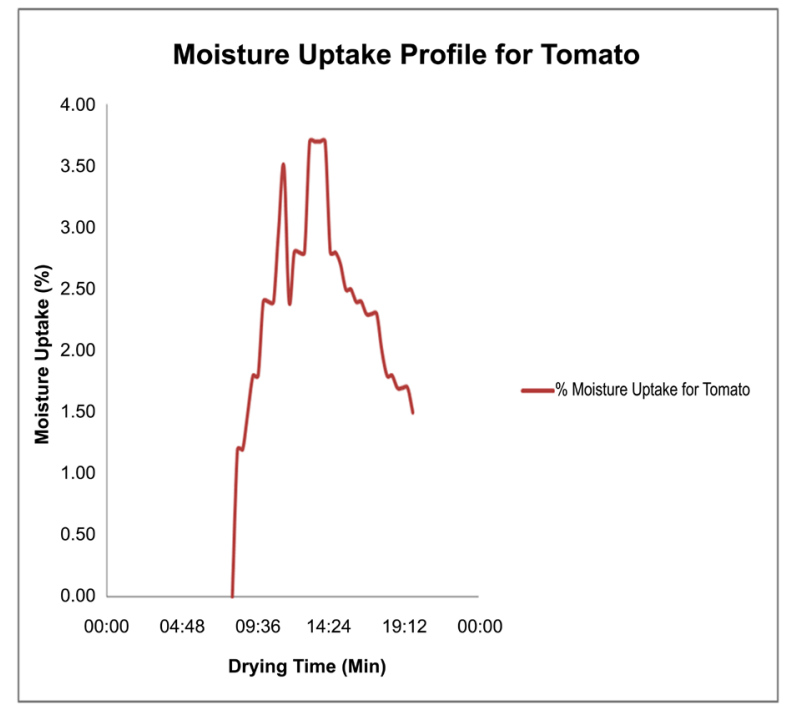

(b)

Figure 5. (a) Drying profile for tomato product; (b) Moisture uptake profile for tomato product.

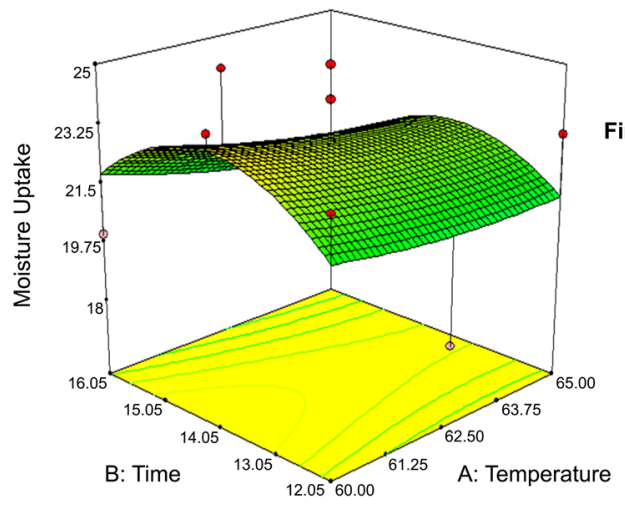

Final Equation in Terms of Actual Factors:

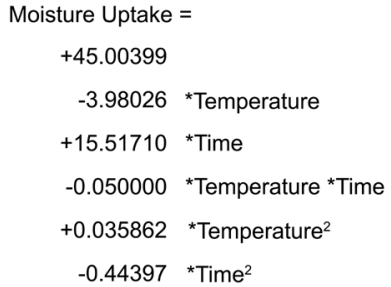

Figure 6. Optimum parameter Response of Cassava product. 
increase in the drying temperature was observed from $31^{\circ} \mathrm{C}$ to $65^{\circ} \mathrm{C}$ between 8:05 till 1:05 pm. This was due to the fact that solar energy was gradually been introduced into the drying process. A steady drying temperature was observed at $65^{\circ} \mathrm{C}$ for about an hour during the course of the drying process. The drying temperature steadily falls from $65^{\circ} \mathrm{C}$ to $34^{\circ} \mathrm{C}$ at $2: 25 \mathrm{pm}$ down till the end of the drying process at about 7:45 $\mathrm{pm}$. This could be traced to the decrease in solar energy, thus limiting the drying process to the heat from the drying chamber.

Figure 4(b) and Figure 5(b) show the rate of moisture uptake of cassava and tomato products respectively. In Figure 4(b), there was a steady increase in the percentage moisture uptake of cassava up to the tune of $3 \%$ from the start to about 2 hours into the drying process. At that time, 79\% of the moisture had been vaporised. This is achievable due to the fact that the dryer was operating at the maximum design temperature of $65^{\circ} \mathrm{C}$. The percentage moisture uptake was gradually reducing thereafter until the $10 \%$ targeted moisture level was achieved. In Figure 5(b), steady rate of moisture uptake was also observed at the initial stage to a tune of $3.5 \%$ within 4 hours of the drying process. A sharp decrease from $3.5 \%$ to $2.4 \%$ in the rate of moisture uptake was observed during the process due to misbehavior in the material used in the combustion chamber thereafter was an increase to the tune of 3.7\% moisture uptake. At that time, 56\% of the moisture had been vaporised. The rate of moisture uptake was observed to decrease until the targeted $10 \%$ moisture level was achieved. Table 4 shows the output of the performance test for the hybrid solar dryer.

\section{Optimisation Results}

Drying process parameters were identified as drying temperature, drying time and percentage moisture uptake. The optimization of the drying parameters was carried out to determine the optimum values of the parameters that will yield the best result.

Table 5 and Table 6 show the some optimum values for drying temperature, drying time and percentage moisture uptake for cassava and tomato products respectively, from series of solution using design expert software. From table 5, the best fit optimum parameters for cassava product are drying temperature of $62.2^{\circ} \mathrm{C}$, at $13: 26$ drying time to achieve $22.84 \%$ moisture uptake. While for tomato products, the best fit optimum parameters are $48.77^{\circ} \mathrm{C}$ drying temperature

Table 4. Summary of the Performance Test for the Hybrid Solar Dryer.

\begin{tabular}{ccc}
\hline S/N & Parameters & Values \\
\hline 1 & Highest Temperature achieved & $65^{\circ} \mathrm{C}$ \\
2 & Light Illumination Capacity & $90 \%$ \\
3 & Velocity of Air & $0.1 \mathrm{~m} / \mathrm{s}$ \\
4 & Final Moisture Content & $10 \%$ \\
5 & Mass of Cassava after Drying & $100 \mathrm{Kg}$ \\
6 & Mass of Tomato after Drying & $334 \mathrm{~g}$ \\
7 & Maximum Loaded Capacity & $250 \mathrm{Kg}$ \\
\hline
\end{tabular}


Table 5. Summary of the Optimum parameters for Cassava Product.

\begin{tabular}{cccc}
\hline S/N & Optimum Drying & Optimum Drying & Optimum $\% \mathrm{H}_{2} 0$ \\
\hline 1 & Temperature $\left({ }^{\circ} \mathrm{C}\right)$ & Time $($ Min $)$ & Uptake \\
2 & 62.19 & 13.26 & 22.84 \\
3 & 63.64 & 15.50 & 21.27 \\
4 & 60.21 & 14.23 & 23.43 \\
5 & 60.25 & 14.02 & 23.42 \\
6 & 64.03 & 15.06 & 21.26 \\
7 & 61.28 & 15.25 & 22.42 \\
8 & 61.22 & 12.28 & 21.76 \\
9 & 62.83 & 14.21 & 22.71 \\
10 & 62.87 & 15.18 & 22.04 \\
11 & 60.89 & 14.17 & 23.2 \\
12 & 62.95 & 13.30 & 22.7 \\
13 & 61.61 & 14.46 & 22.81 \\
\hline
\end{tabular}

Table 6. Summary of Optimum Parameters for Tomato Product.

\begin{tabular}{cccc}
\hline S/N & Optimum Drying & Optimum Drying & Optimum $\% \mathrm{H}_{2} \mathrm{O}$ \\
\hline 1 & Temperature $\left({ }^{\circ} \mathrm{C}\right)$ & Time $($ Min $)$ & Uptake \\
2 & 42.11 & 10.26 & 90.45 \\
3 & 54.07 & 15.25 & 90 \\
4 & 32.48 & 19.16 & 87.45 \\
5 & 38.98 & 10.36 & 90.07 \\
6 & 59.28 & 13.93 & 88.79 \\
7 & 56.14 & 16.78 & 88.89 \\
8 & 48.77 & 13.40 & 91.13 \\
9 & 41.29 & 11.44 & 90.79 \\
10 & 57.44 & 14.85 & 89.22 \\
11 & 61.62 & 14.78 & 87.73 \\
12 & 50.18 & 13.41 & 90.98 \\
13 & 61.49 & 17.29 & 86.71 \\
\hline
\end{tabular}

at 13:40 drying time to achieve 91.3\% moisture uptake. Figure 6 and Figure 7 show optimum parameters responses of cassava and tomatoes products. All the financial implication of design and construction of the hybrid dryer was shown in Table 7.

\section{Limitations}

1) Little or no control on the sources of heat made available in the dryer

2) There is no consistency in the air flow over the product 
Table 7. Bill of engineering material and evaluation of the hybrid dryer.

\begin{tabular}{|c|c|c|c|c|c|}
\hline $\mathrm{S} / \mathrm{N}$ & Items & Quantity & Unit Cost & $\begin{array}{l}\text { Estimated Cost } \\
(\mathrm{N})\end{array}$ & $\begin{array}{c}\text { Estimated Cost } \\
(\$)\end{array}$ \\
\hline 1 & Cement & 80 bags & 1500 & 120,000 & 286 \\
\hline 2 & $\begin{array}{c}\text { Transparent Plastic Material } \\
\text { (Roof) }\end{array}$ & 30 & 3000 & 90,000 & 214 \\
\hline 3 & Moulded Bricks (6 inches) & 100 & 1000 & 100,000 & 238 \\
\hline 4 & Net & 2 & 200 & 400 & 1 \\
\hline 5 & Metal Drum & 3 & 10,000 & 30,000 & 71 \\
\hline 6 & Planks (Softwood, $1 \times 12 \times 12$ ) & 20 & 1400 & 28,000 & 67 \\
\hline 7 & Planks for Ceiling) & 20 & 800 & 16,000 & 38 \\
\hline 8 & Nails & & & 10,000 & 24 \\
\hline 9 & Stainless Steel & 2 sheets & 50,000 & 100,000 & 238 \\
\hline 10 & Gravels (25 tons) & 1 & 30,000 & 30,000 & 71 \\
\hline 11 & Sand ( 25 tons) & 2 & 15,000 & 30,000 & 71 \\
\hline 12 & Paint/Accessories & & & 20,000 & 48 \\
\hline 13 & Labour (Carpenter/Bricklayer) & & & 50,000 & 119 \\
\hline \multirow[t]{2}{*}{14} & Transportation to site & & & 20,000 & 48 \\
\hline & Total & & & 644,400 & 1534 \\
\hline
\end{tabular}

$\$ 1$ is equivalent to $\mathrm{N} 420$.

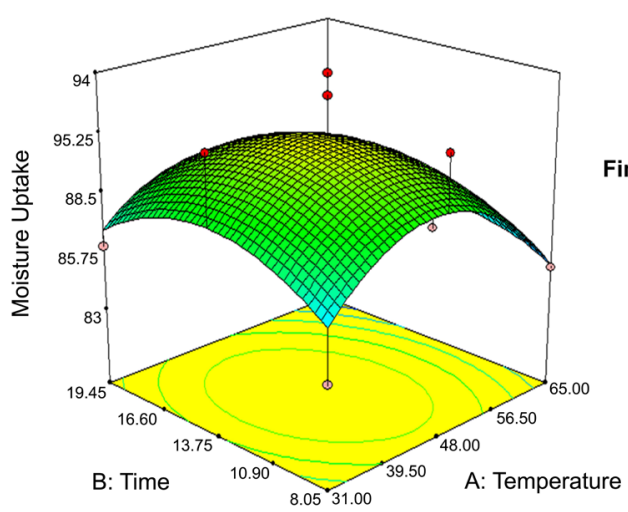

Final Equation in Terms of Actual Factors:

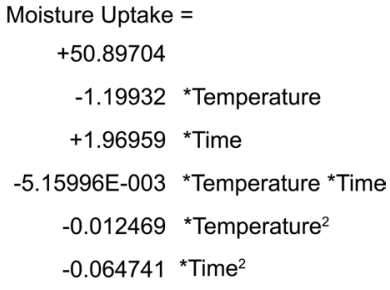

Figure 7. Optimum parameter Response of Tomato Product.

\section{Conclusion}

Solar system of drying is an encouraging technology for drying of food products for less developed country like Nigeria, where there is abundance in solar energy. This can reduce the post-harvest food spoilage which is a major challenge in the country to a large extent. Despite drying condition varies from one product to another, a dryer may be designed to accommodate different products with good checked of parameters such as temperature and the mass flow rate. The performance evaluation of the case study shows a successful design and an evidence of a worthwhile sustainable technology that should be given mass puffery. 


\section{References}

[1] Boiln, H.R. and Salunkhe, D.K. (1982) Food Dehydration by Solar Energy. CRC Critical Reviews in Food Science and Nutrition, 327-354. https://doi.org/10.1080/10408398209527339

[2] Perasiriyan, V., Karthikadevi, B., and Sivakumar, T. (2013) Optimisation of Drying Process for Vegetable and Fish by Solar Tunnel Dryer. International Journal of Food, Agriculture and Veterinary Sciences, 3, 51-57.

[3] Sharma, V.K., Colangelo, A., and Spagna, G. (1995) Experimental Investigation of Different Solar Driers Suitable for Fruits and Vegetable Drying. Renewable Energy, 6, 413-424. https://doi.org/10.1016/0960-1481(94)00075-H

[4] Karathanos, V.T. and Belessiotis, V.G. (1997) Sun and Artificial Air Drying Kinetics of Some Agricultural Products. Journal of Food Engineering, 31, 35-46. https://doi.org/10.1016/S0260-8774(96)00050-7

[5] Bala, B.K., Mondol, M.R.A., Biswas, B.K., Das Chowdury, B.L. and Janjai, S. (2003) Solar Drying of Pineapple Using Solar Tunnel Drier. Renewable Energy, 28, 183-190. https://doi.org/10.1016/S0960-1481(02)00034-4

[6] Gbaha, P., Andoh, H.Y., Saraka, J.K., Koua, B.K. and Toure, S. (2007) Experimental Investigation of a Solar Dryer with Natural Convective Heat Flow. Renewable Energy, 32, 1817-1829. https://doi.org/10.1016/j.renene.2006.10.011

[7] Thepent, V. (2009) Agricultural Engineering and Technology for Food Security and Sustainable Agriculture in Thailand. Country Report, Chiang Rai, APCAEM, Thailand, 1-6.

[8] Davanagere, B.S., Sherif, S.A., and Goswami, D.Y. (1999) A Feasibility Study of a Solar Desiccant Air-Conditioning System Part I: Psychrometrics and Analysis and Analysis of the Conditioned Zone. International Journal of Energy Research, 23, 7-21. https://doi.org/10.1002/(SICI)1099-114X(199901)23:1<7::AID-ER439>3.0.CO;2-U

[9] Thoruwa, T.F., Smith, J.E., Grant, A.D. and Johnstone, C.M. (1996) Developments in Solar Drying Using Forced Ventilation and Solar Regenerated Desiccant Material. Renewable Energy, 9, 686-689. https://doi.org/10.1016/0960-1481(96)88378-9

[10] Riyad, H. and Jacque, B. (2001) Integration of a Desiccant Unit in Crops Solar Drying Installation: Optimization by Numerical Simulation. Energy Conversion and Management, 42, 1543-1558. https://doi.org/10.1016/S0196-8904(00)00159-X

[11] Gurtas, F. and Evranuz, O. (2000) Low Temperature Mushroom (A. bisporus) Drying with Desiccant Dehumidifiers. Drying Technology, 18, 433-445.

https://doi.org/10.1080/07373930008917714

[12] https://en.wikipedia.org/wiki/Ogun_State

[13] Garg, H.P. and Prakash, J. (1997) Solar Energy-Fundamentals and applications. Energy, 60, 151-157.

[14] Tiwari, G.N. (2002) Solar Energy: Fundamentals, Design, Modelling and Applications. Alpha Science International Ltd., Oxford.

[15] Aravindh, M.A. and Sreekumar, A. (2015) Solar Drying-A Sustainable Way of Food Processing. Green Energy and Technology, 1-21.

https://doi.org/10.1007/978-81-322-2337-5_2 